\title{
On the Study of Higher Education in Canadian Universities ${ }^{\dagger}$
}

\section{MICHAEL L. SKOLNIK*}

\begin{abstract}
Although research on Canadian higher education has advanced considerably over the past few decades, the opportunities for university level study of higher education in Canada are still quite limited. Only four universities offer higher education programs; only one has a higher education department; and only a handful of other institutions offer even a course in higher education. The number of students enrolled in higher education programs in Canada is about 200 , compared to about 6,000 in the United States; the number of faculty about 15 compared to 700 in the U.S.

Moreover, while American higher education journals have, since the early 1970's, regularly featured articles about university higher education programs, there has not been a single article on this subject in The Canadian Journal of Higher Education. This paper attempts to fill some of that gap by providing some basic information about the study of higher education in Canadian universities and by examining the role of these programs in the overall development of higher education research and the possible reasons for the very limited scale of such programs in Canada.

The author's conclusion is that the factor which has most limited the development of higher education studies in Canadian universities is neither insufficient student demand nor limited employment opportunities of graduates, but reluctance of Canadian universities to allocate resources for this area of study. This reluctance is attributed to the combination of the low prestige of * Professor, Higher Education Group, Ontario Institute for Studies in Education

$\dagger$ An earlier version of this paper was presented at the Annual Meeting of the Canadian Society for the Study of Higher Education, Kingston, Ontario, June 24, 1991. The author wishes to thank: Mary Jean McGraw for assistance with data compilation and analysis; Glen Jones for commentary on an earlier draft; and heads of higher education programs for response to a survey. The author bears sole responsibility for factual errors if any, and for the opinions stated in the paper.
\end{abstract}


higher education as a field of study and the lack of a strong lobby for this program area outside the university. It is suggested that - in contrast to their American counterparts - presently Canadian higher education programs have less than the minimum resources necessary to make the advances that would be required to overcome this "prestige barrier".

\section{Résumé}

Bien que la recherche sur l'enseignement supérieur au Canada ait fait des progrès considérables au cours des dernières décennies, les occasions de mener des études sur l'enseignement supérieur au Canada, au niveau universitaire, sont encore très limitées. En effet quatre universités seulement offrent des programmes d'enseignement supérieur; une seule d'entre elles a un département d'enseignement supérieur; et un très petit nombre d'autres établissements offrent un cours d'enseignement supérieur. Au Canada, on ne compte que 200 étudiants environ, alors qu'aux États-Unis, ce chiffre atteint presque 6000 inscriptions. D'autre part, on ne compte qu' environ 15 membres du corps professoral comparativement à 700 membres aux États-Unis.

De plus, alors que les revues américaines sur l'enseignement supérieur ont, depuis le début des années 70 , fait régulièrement paraître des articles sur les programmes d'enseignement supérieur à l'université, la revue Société canadienne pour l'étude de l'enseignement supérieur/The Canadian Journal of Higher Education n'a publié aucun article sur ce sujet. Le présent article tente donc de combler cette lacune en donnant quelques informations de base sur l'étude de l'enseignement supérieur en milieu universitaire canadien, et en examinant le rôle de ces programmes dans le développement global de la recherche sur l'enseignement supérieur ainsi que les raisons qui ont pu maintenir de tels programmes sur une si petite échelle au Canada.

L'auteur tire donc la conclusion que le facteur qui a le plus largement contribué à limiter le développement des études de l'enseignement supérieur dans les universités canadiennes ne tient pas à l'insuffisances du nombre des demandes ni du petit nombre de débouchés offerts aux diplômes mais bien plutôt à la façon récalcitrante dont les universités canadiennes prétendent allouer des ressources à ce domaine d'étude. On attribue cette répugnance à deux facteurs: le manque de prestige que connait l'enseignement supérieur en tant que champ d'étude et l'absence d'un groupe de pression externe que favoriserait les programmes dans cen domaine. Ill ressort que, contrairement à leur contrepartie américaine, les programmes d'enseignement supérieur au Canada ne disposent pas même des ressources nécessaires pour surmonter les handicap de prestige. 
One of the characteristics of an emergent field of study is a preoccupation with existential questions about the nature, development, and scholarly stature of the field. Since higher education emerged as an identified area of study in the 1960 's, there have been numerous attempts to define the field, contrast it with more mature fields, and identify strengths, weaknesses, and gaps in the developing literature.

Perhaps the two sets of questions which have most engaged attention in these introspective essays are, first, those pertaining to the scholarly stature of the field and, second, those pertaining to the volume and comprehensiveness of the research output. There has been more emphasis on the first of these questions in the United States and more on the second in Canada, though both have received attention in each country ${ }^{1}$. The reasons for this difference in emphasis are probably that it is premature to address the status considerations of an emerging field of scholarship until there is a sufficient critical mass of scholars and scholarship to mount a challenge at the doors of academic legitimacy; and having a vastly smaller and less nationally integrated higher education research community, Canadians interested in the study of higher education have had to be more concerned than their American counterparts about just overcoming the sheer obstacles to producing a reasonable amount of research.

Thus, during the 1970's and 1980's, while the predominant developmental emphasis of the Canadian Society for the Study of Higher Education was charting the domain of Canadian higher education research literature as a whole and encouraging its expansion, the CSSHE's U.S. counterpart, the Association for the Study of Higher Education, was moving to differentiate scholarly from "other" research, and examine and promote scholarly research and its principal base, the university higher education department or research centre ${ }^{2}$. Both the ASHE's annual meetings and its journal, The Review of Higher Education, regularly feature seminars, presentations, and articles on the development and characteristics of, and issues in, university higher education programs ${ }^{3}$.

By contrast, while the CSSHE has done much to stimulate research about higher education research ${ }^{4}$, it has not made much attempt to differentiate scholarly from "other" research (in its various forms: institutional, popular, journalistic). Nor has there been a single article on university higher education programs in the Canadian Journal of Higher Education, or, except for one annual meeting, presentations on that subject at the annual meetings of the CSSHE $^{5}$.

With the aid of a small survey of heads of higher education programs, this paper attempts to make a small contribution to filling that gap by describing the 
current state of graduate programming in higher education in Canadian universities, and commenting on the role of these programs in the overall development of higher education research in Canada, possible reasons why there has been such limited development of this field within Canadian universities, and a few issues of general interest concerning these programs ${ }^{6}$. A central matter which must be addressed at the outset is that of the nature of higher education as a field of enquiry.

\section{Higher education as a field of study}

A popular orientation in discussions of higher education as a field of study utilises the juxtaposition of field of study and discipline. For example, the book, Higher Education as a Field of Study, begins by addressing the question, "is higher education a field of study or a discipline?" (Dressel and Mayhew, 1974: 1-7). Just recently, the President of the CSSHE, Janet Donald (1991: 1), writing on the same question in the CSSHE Bulletin, introduced the useful distinction between epistemological and sociological criteria for identifying a discipline.

Donald suggests that disciplines are defined epistemologically by such things as having a distinctive body of knowledge, accepted methodologies for research, and "a theoretical framework which would allow us to situate and interrelate our research". Sociological prerequisites of a discipline are organized research and publication mechanisms and formal professional organization. She concludes that by sociological criteria, higher education conforms to the idea of a discipline; but according to epistemological criteria, it is more like a field of study.

Dressel and Mayhew provide additional elements of the epistemological definition of a discipline: a specialized vocabulary and generally accepted basic literature; a recognized place in relation to other disciplines; a dichotomizing of research into pure and applied; and a devotion of considerable effort to solving basic and theoretical questions. They conclude that by these criteria as well as those which Donald considered, higher education is a field of study rather than a discipline.

An additional sociological characteristic of a discipline, suggested by Dressel and Mayhew, which is especially pertinent to this paper, is the existence of "a recognized sequence of experiences for the preparation of scholars and research workers ..." (p. 5). Normally, the principal element of this recognized sequence is a university degree in the discipline, an observation which reflects two conditions: (a) that for each discipline there are normally widely offered 
programs of university study leading to degrees in the corresponding discipline; and (b) those degrees are normally expected of people working as professionals in the field. By this criterion, higher education is a very long way from being a discipline. Not more than a handful of those who are involved professionally in the study of higher education in Canada actually possess a degree in higher education; and, as we will see shortly, the opportunities for obtaining a university degree in higher education are quite limited.

Besides satisfying one of the sociological criteria of a discipline, how important to the development of higher education as a field of study is it that there be university degree programs in this field? From a purely quantitative perspective in regard to the aggregate volume of higher education research, the potential contribution of such programs may not be so significant. Sheffield reported in 1982 that there were about 750 individuals engaged in higher education research in Canada, of whom only 15 were faculty in university higher education departments or centres (p. 4). He noted also that only two of these 15 spent more than half their time on research due to the demands on their time of teaching and administration 7 . Faculty in higher education departments/centres make up such a small proportion of the total cadre of higher education researchers that even with a substantial increase in their numbers, they would still be vastly outnumbered by others.

However, the value of the contributions of university programs could be greater than that indicated by the ratio of the number of higher education faculty to the total number of higher education researchers, which Sheffield estimates as 1:50. For example, an argument could be made that if the study of higher education is to advance with respect to the rigour and comprehensiveness of its theoretical frameworks and methodological coherence, the impetus for doing so most likely will come from university-based scholars who specialize in the study of higher education. Such individuals are appropriately situated to have an appreciation of the foundations of scholarship and developments in methodology in those disciplines which it is important for higher education to draw upon, and, as Sheffield notes, a "perspective on the whole field [of higher education which would enable them to] help to integrate the efforts of the many others whose interest in PSE is secondary" (p. 8). The example in the United States, of the accomplishments of several hundred professors of higher education working under the umbrella of the Association for the Study of Higher Education, in developing very useful taxonomies, books of readings, and a comprehensive publications program, indicates what can be done with a sufficiently large group of this type. Also, issues pertaining to appropriate 
theoretical frameworks and methodologies for the study of higher education are frequently the subject of articles in The Review of Higher Education, written almost exclusively by professors or higher education (for a survey see Conrad, 1989).

Encouraging as these developments may be to some, there are critics of the academic professionalization of the study of higher education. George Keller (1985), author of the well known book, Academic Strategy (1983), complains that much of the higher education research emanating from universities is trivial - a charge, of course, that is frequently levelled at many disciplines, and may, in fact, be an additional criterion of being a discipline. Others charge that professors of higher education are too divided in interest, "mired in detail and inclined to speak primarily to one another" (Newell and Kuh, 1989: 88). Yet others complain of the conservatism of academic study of higher education, noting that the vast bulk of current journal literature is all in the same functionalist mold, with other methodological cells such as radical structuralist or interpretive remaining empty (Milam, 1990: 40).

Given these types of criticism, one should be cautious in making claims about the potential contributions of university higher education programs. Nevertheless, such programs could have a special place in the national infrastructure for higher education research: they should be a permanent repository of expertise in the theories, methodologies, and empirical knowledge of higher education, broadly defined; they should be a critical agent for application and dissemination of new ideas; they can provide the locus for interface with the broader scholarly community; and they are the training ground for the next generation of scholars who will have the responsibility for subsequent advances in the field and the major location for sustained professional development for higher education researchers and for many practitioners. For all these reasons, examination of the state of educational programs in higher education in Canadian universities should be of interest to others besides professors and students in these programs. However, because of the influence of American programs upon the development of higher education programs in Canada, it is useful to first look briefly at the development of higher education programs in the United States.

\section{Development of higher education programs in the U.S.}

The idea of offering university courses on higher education dates back to the late nineteenth century. During the early years of The Johns Hopkins University, 
psychologist G. Stanley Hall proposed to the president of the university that Hall offer a course on the history of universities and learned societies. Hall reasoned that such a course would equip the many Johns Hopkins graduates who subsequently took positions in colleges and universities to function more effectively in an academic milieu. The President of Johns Hopkins, however, did not concur, and the course was not implemented until a few years later when Hall became president of his own university, Clark University, where the first higher education course is reputed to have been provided in 1893 (Williams, 1984: 175). Similar courses were introduced at a number of American universities over the next half century, all reflecting what is still one of the principal rationales for university higher education programs: "that people committing lifetime careers to working in colleges and universities might benefit from an understanding of the history and organization of higher education" (Williams, p. 176).

The next phase in university study in higher education in United States, occurring between 1945 and 1960, was marked by higher education programs becoming a significant vehicle for entry into administrative positions in colleges and universities and was noteworthy for the first appointments of full-time professors of higher education. Since 1960, additional aims have been added to providing a general understanding of higher education and preparing people for administrative careers. These include in-service training for persons who came to administrative positions from other routes; research, particularly the development of a knowledge base for addressing questions of higher education policy; and training new professors of higher education to meet the needs of an expanding market and to provide replacements, as members of the earlier generation of this group began to retire.

By 1984, there were more than 80 higher education programs, enrolling over 5,000 students, and involving over 700 faculty, close to half of them full-time 8 (Crosson and Nelson, 1986). Of the total enrolment, about three-fourths was at the doctoral level, two-thirds was part-time. The modal number of full-time faculty per program was between three and four, and over a third of programs had more than four full-time faculty.

While the three categories of aims noted above - imparting an understanding of higher education, training for administrative jobs, and preparation of scholars and researchers - are all represented, the primary purpose of over 90 per cent of the programs is the preparation of administrators for colleges and universities (Townsend and Wiese, 1990:2). Half or more of the programs include the following areas of specialization, in order of frequency: student personnel 
administration/student affairs, administration and/or management, academic administration, and community college administration/community college.

While a degree in higher education is not often required for administrative positions in colleges and universities, in a recent survey by Townsend and Wiese it was found to be preferred to a degree in an academic discipline by many institutional employers for some positions - particularly for student affairs dean in community colleges. While Townsend and Wiese cite studies which show that of college and university administrators who possess a doctorate, from 14 to 20 per cent have them in higher education, there are no trend data on these figures, or on employer perceptions of the higher education degree, and they report a concern of many that the market for recipients of these degrees may be saturated (p. 3).

Whatever the administrative job market prospects for graduates may be, it is important to note that not all programs focus primarily on that objective, and that even insofar as preparation of administrators is a goal, there are differences of opinion as to the appropriate curriculum emphasis for that goal. Many higher education faculty believe that the best way to do this is to provide a sound theoretical, historical, and institutional understanding of higher education, rather than inculcating specific "how to" skills, like making a budget or doing a performance appraisal, which are often quite context-specific and are thought best learned on the job. This idea was reflected well, for example, in the brochure for prospective students in the SUNY, Buffalo doctoral program in higher education, several years ago, when that institution had a relatively large program which was rated by peers as one of the most prestigious in the United States: "The Department does not provide training in administrative skills for individuals for such careers, rather all of its students are expected to achieve a breadth and critical sophistication which will undergird their service in whatever position they hold" (quoted in Dressel and Mayhew, p. 160). Of this type of goal statement, Dressel and Mayhew say, "Unless departments of higher education are prepared to more carefully define and demonstrate the validity of formal training of educational administrators, they would do better to adapt the SUNY (Buffalo) stance which is unequivocal, realistic, and probably as strong a statement as can reasonably be made in terms of our current knowledge and evidence" (p. 160). Moreover, in spite of the strong vocational emphasis in the development of higher education programs in the United States and the tendency to develop numerous specializations related to different career streams, the programs which are regarded as most prestigious are more generalist, less skill oriented, less instrumental, and put more emphasis on theory (Murrell and Davis, 1990). 


\section{Higher education in Canadian universities}

Edward Sheffield has observed that Canada was "slow to make higher education a specialized field of study" (1970:1). Because of the ambiguity surrounding the term program it is difficult to say definitively when the activity related to higher education studies in various universities first actually represented a program in higher education. Probably the first milestone was in 1964 when Robin Harris was appointed Canada's first professor of higher education, in the University of Toronto. Within the next year, programs developed at both Toronto and $\mathrm{UBC}$, and these two were joined by the University of Alberta in 1970 and the University of Manitoba in $1978^{9}$.

These four programs - UBC, Alberta, Manitoba, and OISE - are the only Canadian programs listed in the ASHE Directory of higher education programs in North American universities. While there may be different types of opportunities for graduate students to specialize in topics related to higher education in other universities, it is arguably the case that these are the only higher education programs in Canada ${ }^{10}$. In fact, in scanning calendars of faculties of education of Canadian universities, we found only five institutions besides the four noted in Table 1 which listed a course that mentioned higher or postsecondary education explicitly in the title or prominently in the course description in the calendar ${ }^{11}$. Although faculty of education courses may give more attention to higher education than this scan of calendars reveals, those faculties which do not have higher education programs do not exactly give the impression of promoting the study of higher education. Either there are not many in Canadian faculties of education who feel as Stanley Hall that a course in higher education would be very useful for anyone who is intent upon an academic career - or they have been thwarted by deans with the same view as the President of Johns Hopkins.

Some basic information about the four Canadian higher education programs thus identified is provided in Table 1. The first row of the Table shows that only at OISE is there an academic department exclusively devoted to the study of higher education. In the other three institutions, higher education programs are located within larger, composite departments which also offer educational administration and/or adult education - at the University of Alberta, higher education is offered through two departments: Adult, Career, and Technology Education, and Educational Administration. OISE is also the only one of the four institutions which offers all four degrees in higher education: M.Ed., M.A., Ed.D., and Ph.D. Manitoba and Alberta offer only M.Ed. and Ph.D. degrees in higher education, and British Columbia all but the Ph.D. 
Table 1

Some Aspects of Higher Education Programs in Canadian Universities, 1990/91

\begin{tabular}{|c|c|c|c|c|c|}
\hline & U of Alberta & U. B. C.. & U of Manitoba & OISE & Total \\
\hline $\begin{array}{l}\text { Unit in } \\
\text { which } \\
\text { program } \\
\text { is located }\end{array}$ & $\begin{array}{l}\text { Depts. of Adult, } \\
\text { Career \& Tech. } \\
\text { Ed./Ed. Admin. }\end{array}$ & $\begin{array}{l}\text { Dept. of Admini- } \\
\text { strative, Adult, \& } \\
\text { Higher Ed. }\end{array}$ & $\begin{array}{l}\text { Dept. of Educa- } \\
\text { tional Admin. \& } \\
\text { Foundations }\end{array}$ & $\begin{array}{l}\text { Higher Ed } \\
\text { Group }\end{array}$ & \\
\hline Specializations & $\begin{array}{l}\text { Admin. Leader- } \\
\text { ship, Curr. \& } \\
\text { Inst. E.S.L. }\end{array}$ & $\begin{array}{l}\text { Comm. Colleges } \\
\text { Organ. \& Admin. } \\
\text { Adult Education } \\
\text { Institutional Research }\end{array}$ & $\begin{array}{l}\text { Gov. \& Admin. } \\
\text { Teach. \& Learn. }\end{array}$ & $\begin{array}{l}\text { Hist.\& Phil. } \\
\text { Admin. \& Plan. } \\
\text { Comp. Higher Ed. } \\
\text { Teach. \& Learn. } \\
\text { Professional Ed. } \\
\text { Health Prof. Ed. }\end{array}$ & \\
\hline \multicolumn{6}{|l|}{ Enrolment } \\
\hline Full-time & 30 & 5 & 5 & 37 & 77 \\
\hline Part-time & 35 & 36 & 28 & 75 & 174 \\
\hline Doctoral & 20 & 5 & 3 & 58 & 86 \\
\hline Master's & 45 & 36 & 30 & 54 & 165 \\
\hline TOTAL & 65 & 41 & 33 & 112 & 251 \\
\hline \multicolumn{6}{|l|}{ Faculty } \\
\hline Fulltime & 7 & 1 & 1 & 5 & 14 \\
\hline Parttime & 4 & 1 & 3 & 3 & 11 \\
\hline Adjunct & 9 & 2 & 2 & 7 & 20 \\
\hline
\end{tabular}


Not surprisingly given the location of higher education programs within a department which also has responsibility for educational administration programs in three of the four cases, some variant of higher education administration is a common specialization. All four programs offer this specialization, though the emphases may vary among leadership, organization, governance, and planning. The only other specialization common to at least three institutions is that of teaching/learning/curriculum in higher education. Several specializations are offered at only one institution, for example, comparative higher education, community colleges, or health professional education. The latter is a relatively new specialization which OISE offers in cooperation with the University of Toronto's Faculty of Medicine and which caters to individuals pursuing careers as educators in medicine and other health fields such as physiotherapy, dentistry, and nursing. Apart perhaps from this specialization, there is considerable overlap among the specializations shown in Table 1, and as will be noted subsequently, there is some question as to the significance of specialization within the field of higher education.

The third and fourth sections of Table 1 provide estimates of the numbers of students and faculty in the higher education programs. In regard to the higher education programs offered by composite departments (all except OISE), these figures - especially the faculty figures - should be interpreted with caution. Few faculty in these departments work exclusively in the higher education programs. The figures in the Table represent the program heads' best estimates of the number of faculty in those departments whose primary orientation is higher education. Some of the working time of these individuals may be spent on other departmental programs/specializations, and in turn, other faculty may contribute time to the higher education program. The classification of persons in a composite department by program is much less of a problem for students than faculty, because students designate the degree or specialization toward which they are working. However, in the case where a student is focussing upon a higher education subject within another specialization in the department, he or she might not be picked up in Table 1. And of course, a student in another department at OISE, such as Educational Administration, doing a doctoral thesis on, say, leadership in community colleges, would not be counted in Table 1; nor, for that matter, would students in cognate departments in any of the four universities, e.g. someone in an Economics Department working on the economics of higher education. The figures in the Table are intended to provide the best estimates of students and faculty actually engaged in higher education programs in Canadian universities. 
In comparison with the corresponding figures for the United States, the numbers in Table 1 are very small. The 251 students represent about one twentieth to one thirtieth of the number enrolled in higher education programs in the U.S., depending upon which figure one accepts for the U.S. total. Also of note is that doctoral students comprise only about a third of Canadian enrolment, and about a fifth outside of OISE, compared to about three-fourths in the U.S. Enrolment at the doctoral level in Canadian higher education programs is thus about one fiftieth of that in the U.S. The estimate of 14 full time faculty is consistent with the figure of 15 which Sheffield estimated for 1982, though the distribution by institution differs between the two studies. The number of full time faculty in higher education programs in Canada does not seem to have changed in the past decade, and it represents about one thirtieth of the number in the United States.

The limited number of programs, and more so, the limited enrolment and staff, raise two questions: is the study of higher education in Canadian universities of less than optimal scale, and if so, why has this area of study not achieved a greater scale? There are a variety of approaches to answering the first question, none of them without serious objection. Three criteria commonly employed to determine the appropriate scale of a program are student demand, social need, and critical mass. The present survey reveals a perception among program heads that present enrolment levels are less than optimal from the point of view of student demand, though the extent of excess demand depends very much upon how admission requirements are set, a quite controversial issue in some institutions.

Social need can be operationalized in a variety of ways, the most common way being in terms of employer demand. As there has been no study of the employment demand for graduates of Canadian programs, it is not possible to draw any conclusions about how well present levels of enrolment meet this demand. In Canada, unlike the U.S., it is not clear that the higher education degree has yet become a preferred labour market credential - possibly because there have not been a sufficient number yet to have established a market value. The perception of higher education program heads, though, is the employment market is not at all a limiting factor on scale of programs at present.

The very small number of full-time faculty in each program only barely constitute a minimum critical mass, if they do at all. In most cases it has not been difficult to get adjunct or associated faculty, with small or nominal appointments, to do some teaching and thesis advising, and the opportunity to involve diverse faculty in this way has been seen as a source of strength and 
enrichment. However, the downside is that core faculty can be overwhelmed by the demands of program planning and administration, advising, and service work that realistically can be borne only by full-time faculty. While many academic units can perhaps make a plausible case that they are understaffed, having only one or two people seems compelling evidence.

It is not clear why university programming in higher education in Canada is of such a meagre scale. When asked what factors have contributed most to limiting the scale of higher education programs, program heads rated staffing and resource constraints as the only or main factor. This, of course, leads to the question of why universities have been so reluctant to provide staff for higher education programs. Part of the answer lies in the fact that higher education emerged as a field of study fairly recently, during a period when it has been difficult for most units to obtain additional resources. Another factor is that higher education programs do not have the large and strong constituencies outside the university which some professional programs have.

But the most important factor is probably that, as a field of study, higher education has very low status within the academic community. The basis of the low status of higher education studies within the academy lies in a combination of parochialism and being a field of study rather than a discipline. While they do not often attain the prestige of a discipline, fields of study can gain a considerable amount of prestige, e.g. international studies, industrial relations, cognitive science, or media studies. In such cases, the vast majority of academics do not possess first hand knowledge of the subjects of study and tend to defer to the expertise of those who specialize in these fields, even if all the theories and methodologies used in these fields are derived from other fields, as it is with respect to higher education. In the latter case, however, every academic considers him/her self an expert on the subject and is thus unlikely to recognize the special expertise of those who specialize in the field (Skolnik, 1987).

The tenuousness of higher education programs in Canadian universities is reinforced by other characteristics noted above - those pertaining to predominant level of study and patterns of specialization. Much greater prestige in the university is associated with the doctoral than with the master's level. In the United States - where higher education programs enjoy relatively greater stature and support than in Canada - more than three fourths of enrolment is at the doctoral level, and half the master's students are in a predoctoral stream (Glazer, 1987). Many programs, including several of the ones rated as most prestigious in a national survey, do not offer the master's degree. There is, 
however, a chicken-and-egg problem with respect to level of enrolmentprestige-resources connection. Master's programs require fewer faculty per student than doctoral programs, so stringent resource constraints, as Canadian higher education programs operate under, almost guarantee high master's to doctorate ratios, which, in turn, work to limit the prestige of the field ${ }^{12}$.

The specialization issue illustrates the type of difficulty which higher education programs may encounter when judged from the perspective of a discipline. Specialization has been central to the development of the disciplines, and discipline knowledge is routinely compartmentalised in horizontal classifications and vertical hierarchies. Illustrative of the way in which the virtues of specialization are taken for granted in the scholarly community is the following statement about the characteristics of quality graduate programs, disseminated by the body which appraises graduate programs in Ontario:

Graduate study is an exercise in focus on a particular area of concern or type of issue. One of the features of undergraduate work is the attempt to cover the breadth, or the domain, of a discipline or subject. At the graduate level, a department has decided which parts (or fields) within the broad domain of study it does best, and focuses its resources on those particular areas (OCGS, 1990: 2).

Fitting as this admonition may be for biology, physics, or economics, there are several reasons for doubting its suitability for a field like higher education. For one thing, as a first degree program, higher education has in common with undergraduate programs that it must acquaint students with the full range of the field. And in contrast to some first degree professional programs, higher education programs do not emphasize the development of specific practitioner skills. The tendency of the best American programs to be generalist in nature was noted earlier. When heads of Canadian programs were asked to rate their objectives on a scale where 1 represented "emphasis on specific practitioner skills", and 7 represented "emphasis on breadth of knowledge and critical thinking about higher education", only in the case of a single M.Ed. program was the response less than a 6 .

A second, and quite practical consideration, is that with only a few higher education programs dispersed over a vast nation, adhering to exclusive specialization would do a great disservice to students. It could mean, for example, that a student, even one who wants to do a part-time Master's degree, might be forced to travel thousands of miles within Canada or go to the United 
States to study the area of higher education that is most relevant to his needs, especially in areas such as student development, postsecondary finance, or professional education.

Almost any topic in higher education can be studied in some disciplinary department. However, in such case, it would be studied from the perspective of that discipline, as an application of a particular model or theory in that discipline. Likely it would be studied somewhat differently within a higher education program, where there would be an attempt to relate work on that topic to other literature and issues in higher education. Higher Education is an inherently interdisciplinary field, and at least in its present phase of development, the emphasis should be on drawing together insights, theories, methods, and so on from various sources and trying to create a common framework examining interrelated phenomena. Otherwise a higher education department would simply be a collection of specialists from other disciplines, each focussing on a particular application of his or her discipline to higher education.

The value placed on synthesis in Higher Education stands in contrast to the veneration of reductionism in the mainstream scholarly community. The specializations listed in Table 1 bow to this norm, but they are quite broad, overlapping, and elastic. In reality, our mission could as appropriately be described as a rarefied form of advanced general education, as it could be thought to conform to the conventional notions of graduate study in the disciplines, as described in the quotation above. But the consequence of not conforming to those norms is consignment to the bottom rung of the prestige hierarchy, and the material impoverishment that goes with occupying this rung. This, with the added catch that lacking the critical minimum of resources nationally, the advances in scholarship which might possibly help surmount the "prestige barrier" are not possible, and the university higher education program remains a marginal and fragile enterprise in Canada.

\section{Notes}

1 In this paper, the author draws upon published information about the study of higher education in the United States and makes frequent comparisons between Canada and the United States. Although uniquely Canadian in some respects, the study of higher education in Canada is heavily influenced by developments in the United States and is substantially embedded in a North American scholarly and professional community. As some current research by Glen Jones (1991) shows, Canadians writing about higher education cite American works at least as frequently as they cite Canadian works; most of the leading texts on theory and methodology are American; American programs have 
been used, to varying degrees, as models in developing higher education programs in Canada, and American scholars are often brought in to evaluate programs here. For these reasons, information on the study of higher education in the United States provides a valuable context for examination of this subject in Canada, though it is important to be mindful of cultural and institutional differences in higher education between the two countries in drawing any conclusions about the study of higher education in Canada.

2 In the United States, there are two national societies which are interested in the study of all aspects of higher education and hold annual conferences and publish a scholarly journal, the other one being the American Association for Higher Education (AAHE). The AAHE is much larger than ASHE and has many more practitioners relative to the number of academics than ASHE. ASHE grew out of an association of professors of higher education which broke away from AAHE in order to give more concentration to academic research (and discussion of university-based higher education programs). The CSSHE has features in common with both AAHE and ASHE. The composition of our membership has a much smaller proportion of professors of Education than ASHE, but the programs for our annual conference are more like those of ASHE, with its emphasis on scholarly research, than like AAHE with its greater emphasis on practice.

3 Only those articles from The Review and elsewhere which have been cited in the text of this paper appear in the list of references appended. The author found more than a dozen other articles on university higher education programs in The Review and several in other American education journals.

4 Besides the major study by Sheffield (1982), the CSSHE encouraged reviews of the contributions of sociology, psychology, and economics, respectively, to the study of higher education, by Robert Pike, Janet Donald, and David Stager; an analysis of the contents of the Canadian Journal of Higher Education by John Kirkness; and just recently worked with the Association for Canadian Studies and the Secretary of State of Canada to have a review of higher education as a field of inquiry in Canada produced (Dennison, 1992, forthcoming).

5 Sheffield (1982) cites several presentations on university programs at the 1980 Meeting of CSSHE, each of them referred to as "notes" for presentation or discussion.

6 There are a number of issues which would be of considerable interest to faculty and students in these programs, e.g. admission requirements, core courses, required courses in statistics and research methodology, internships, supervision loads, and so on. While some of these relatively narrow issues may have implications for the broader community of persons interested in higher education research, I will concentrate in this paper on issues likely to be of more general interest. If there is sufficient interest on the part of faculty and student members of CSSHE, possibly they could meet to discuss programmatic issues in conjunction with the annual meeting as occurs with ASHE meetings. 
7 Dressel and Mayhew are more harsh (and sweeping) on this point: "Higher education degree programs generally have not produced significant research; nor are they likely to. The teaching loads and demands for advising graduates, plus other professional responsibilities, allow too little time" (p. 75). This view, of course, ignores the contribution of research done by students in these programs, which is often considerable.

8 Reliable estimates of enrolment and staffing have been difficult to obtain owing to the difficulty of defining "higher education program", identifying all programs, and getting complete and consistent responses. Thus, Crosson and Nelson state that they "guess" that there were between 80 and 90 programs in 1984, the year of their survey. While they report figures of 645 and 5,767 respectively for faculty and student totals, they add that allowing for programs which did not respond, the true figures could be 700 to 800 faculty and 6,800 to 7,600 students. Except where noted, I use data from the Crosson and Nelson 1984 survey because it was more comprehensive and formally treated than the 1989 survey (unpublished) which Nelson reported at the meeting of program directors held in conjunction with the 1990 ASHE Meeting (Nelson, 1990). The latter survey showed a significant decline in enrolment from 1984 to 1989 , but the two samples are not exactly the same. Incidentally, these and other surveys reported in The Review or at ASHE Meetings cover all programs listed in the ASHE Directory, including the Canadian ones, and acknowledge that they give North American rather than U.S. totals.

9 It can be left to the archivists to determine whether it was Toronto or British Columbia which actually had the first formal program of graduate study in higher education. In 1977/78, the administrative and financial responsibility for the University of Toronto program was formally transferred to OISE. Of course, like all other degree programs operated by OISE, academically the higher education program is a University of Toronto program.

10 While it might seem simple to identify higher education programs, neither the term "program", nor "higher education", are unambiguous. For example, while the University of British Columbia has formally designated M.A. and M.Ed. degrees in Higher Education, a student wishing to specialize in Higher Education at the doctoral level must formally do an Ed.D. in Educational Administration or Adult Education. A student doing that option could have a program of studies which would be very similar to that of an Ed.D. student in OISE's Ed.D. in Higher Education, which is a formally designated degree, and would likely be supervised by a professor who is attached to the UBC Master's program in Higher Education. Thus, it is probably fair to say that UBC has a de facto, if not de juris, doctoral program in Higher Education. To take another example, within the Department of Educational Psychology and Counselling at McGill University, students may specialize in teaching and learning, student development, and postsecondary program evaluation, in conjunction with the work of the Centre for University Teaching and Learning. According to Professor Donald of the Centre, there 
are presently ten students pursuing this option, eight of them at the Master's level. Because this is not a formally designated program, even at the Master's, and because the focus is limited to just certain aspects of higher education, it has not included it in Table 1, though in some respects it could certainly be regarded as a Higher Education Program. As for other institutions, in his 1982 study, Sheffield stated that there are seven universities in which "groups of staff and graduate students specialize in the study of postsecondary or higher education" (p. 6). He included Victoria, Calgary, and Montreal, but in 1991 the author did not find what he would term higher education programs in these institutions.

11 Besides the McGill courses on teaching and learning and instructional design, the others are: Saskatchewan (addressing postsecondary faculty in a course on women $\&$ the teaching profession, postsecondary education in a course on technology, society, and education, and postsecondary education in a course on competency-based instruction); Windsor ( a course on organization and administration of postsecondary education); Regina ( a course on educational planning); and Victoria (a college and university option in a counselling practicum). There are, of course, some courses in faculties other than education which deal with higher education, for example, an economics of education course in a department of economics or a sociology course on professions, social stratification, or sociology of education. These would involve looking at higher education from the perspective of a discipline, and would not likely serve President Hall's goal of providing a broad understanding of higher education for those who (will) work in an academic milieu.

12 This paragraph only scratches the surface in regard to the master's-doctoral issue. A common complaint in higher education programs which offer both degrees is that there is no differentiation in the coursework for the two, and that master's students are placed in the same classes largely in order to generate revenue for the doctoral program. Dressel and Mayhew, in fact, express concern that master's students are being shortchanged by departments which see them only as a milk cow to pay for the more preferred doctoral programs and devote the vast bulk of faculty attention to the latter.

\section{References}

ASHE Membership and Higher Education Program Faculty Directory. (1990). College Station, Texas and Washington, D.C.: Association for the Study of Higher Education and ERIC Clearinghouse on Higher Education.

Conrad, Clifton F. (1989). Meditations on the ideology of inquiry in higher education: exposition, critique, and conjecture. The Review of Higher Education, 12 (3), 199220.

Crosson, Patricia H., and Nelson, Glenn M. (1986). A profile of higher education doctoral programs. The Review of Higher Education, 9 (3), 335-357. 
Dennison, John D. (1992, forthcoming). Higher education as a field of inquiry in Canada. In Alexander D. Gregor (ed.). Higher Education in Canada. A monograph prepared under the supervision of the Association for Canadian Studies for the Department of the Secretary of State of Canada.

Donald, Janet. (1991). Are we a discipline? CSSHE Bulletin, Winter Edition, 1.

Dressel, Paul L., and Mayhew, Lewis B. (1974). Higher education as a field of study. San Francisco: Jossey-Bass Publishers.

Glazer, Judith S. (1987). The master's degree in higher education. A paper presented at the Twelfth Annual Meeting of the Association for the Study of Higher Education, Baltimore, Md. (ED 292 387).

Jones, Glen A. (1991). Internationalism or academic chauvinism: An analysis of educational research published by Canadian journals. A paper prepated for the annual meeting of the Canadian society for the study of higher education, Kingston, Ontario, June 2-4, 1991.

Keller, George. (1983). Academic Strategy. Baltimore: Johns Hopkins University Press.

Milam, John H. Jr. (1990). Paradigms of theory in higher rducation. A paper presented at the fifteenth annual meeting of the Association for the Study of Higher Education, Portland, Oregon, Nov. 1-4.

Nelson, Glenn. (1990). Current Review of Higher Education Programs. A presentation to a meeting of Higher Education Program Directors held in conjunction with the 1990 ASHE Meeting in Portland, Oregon, Nov. 1, 1990 (unpublished).

Newell, L. Jackson, and Kuh, George D. (1989). Taking stock: The higher education professoriate. The Review of Higher Education, 13 (1), 63-90.

OCGS. (1990). The appraisals process in Ontario. Toronto: Ontario Council on Graduate Studies.

Sheffield, Edward F. (1970). Origins of the Canadian Society for the Study of Higher Education. Notes for a Lecture at the First Annual Meeting of the CSSHE, Winnipeg, May 29.

Sheffield, Edward F. (1982). Research on postsecondary education in Canada. Ottawa: Social Sciences and Humanities Research Council of Canada.

Skolnik, Michael L. (1987). Role conflicts of a professor of higher education: an autobiographical case study. In Waris Shere and Ronald Duhamel (eds.), Academic futures: Prospects for postsecondary education. Toronto: OISE Press.

Townsend, Barbara K., and Mason, Stephen O. (1990). Career Paths of Graduates of Higher Education Doctoral Programs. The Review of Higher Education, 14 (1), 63 81 .

Townsend, Barbara K., and Wiese, Michael. (1990). Administrative perceptions of the value and content of higher education doctoral programs. A paper presented at the fifteenth annual meeting of the association for the study of higher education. Portland, Oregon: Nov. 1-4.

Williams, Don. (1984). Whither the study of higher education? The Review of Higher Education, 7 (2), 175-186. 